\title{
PERBEDAAN PERSEPSI DAN HARAPAN WISATAWAN LOKAL DENGAN WISATAWAN ASING TERHADAP KUALITAS LAYANAN DI CANDI BOROBUDUR
}

Arif Dwi Saputra ${ }^{1}$, Heni Susilawati ${ }^{2}$, Hary Hermawan ${ }^{3}$

${ }^{1,2,3}$ Sekolah Tinggi Pariwisata AMPTA Yogyakarta, Indonesia, Email:

\begin{abstract}
ABSTRAK
Histori Artikel

Upaya peningkatan wisatawan mancanegara berkaitan dengan daya tarik wisata perlu dimaknai melalui sikap wisatawan mancanegara dalam

Submitted:

1 Juli 2019

Reviewed:

1 September 2019

Accepted:

15 Oktober 2019

Published:

15 November 2019 mempersepsikan dan ekspektasinya terhadap kualitas layanan, sehingga menjadi titik sentral yang lebih terukur ketika ingin mendongkrak devisa negara melalui sektor jasa pariwisata. Penelitian yang telah dilakukan adalah penelitian eksploratif dengan metode deskriptif kuantiatif. Hasil penelitian menunjukan bahwa terjadi perbedaan persepsi dan expetasi kualitas jasa di Candi Borobudur pada kedua kelompok wisatawan
\end{abstract}

Kata Kunci : persepsi, expetasi, wisatawan, Candi Borobudur

\section{DIFFERENCES OF PERCEPTIONS AND EXPECTATIONS OF LOCAL TOURISTS WITH FOREIGN TOURISTS TO THE QUALITY OF SERVICES IN BOROBUDUR TEMPLE}

\begin{abstract}
Efforts to increase foreign tourists related to tourist attraction need to be interpreted through the attitude of foreign tourists in their perception and expectations of service quality, so that it becomes a more measurable central point when wanting to boost foreign exchange through the tourism service sector. The research that has been done is explorative research with the descriptive quantitative method. The results showed that there were differences in perception and experience of service quality in Borobudur Temple in both groups of tourists
\end{abstract}

Keywords: perception, experience, tourists, Borobudur Temple

\section{PENDAHULUAN}

Indonesia merupakan negara yang terdiri dari ribuan pulau sehingga memiliki keanekaragaman budaya, mulai dari suku budaya, adat istiadat hingga kekhasan daerah yang unik berbeda satu sama lain, hal ini merupakan suatu daya tarik yang sangat potensial untuk dipelajari. Budaya merupakan suatu cara hidup yang berkembang dan dimiliki bersama oleh sebuah kelompok orang 
dan diwariskan dari generasi ke generasi, sehingga budaya perlu dijaga dan dilestarikan kelangsungannya.

Pariwisata merupakan salah satu fenomena budaya apabila ditinjau dari sisi subjek (wisatawan) sendiri, hal ini terkait dengan adanya motivasi perjalanan wisatawan, Motivasi perjalanan wisatawan yang meliputi aspek-aspek budaya, ingin melihat adat istiadat negara lain yang berbeda dari negaranya atau keinginan melihat adat istiadat daerah lainnya yang berbeda dengan daerahnya sendiri (http://www2.unwto.org, diakses 17 September 2018).

Perekonomian dunia selama dua dekade terakhir mengalami ektensif sosial dan ekonomi transformasi, salah satunya dalam industri pelayanan jasa terutama dalam industri pariwisata yang setiap tahunnya mengalami kenaikan pertumbuhan yang signifikan. Sehingga United Nation World Tourism Organization (UNWTO) memprediksi pada tahun 2020 industri pariwisata akan menjadi suatu industri terbesar di dunia dan sumber utama pendapatan negara.

UNWTO dalam Tourism 2030 Study menyatakan bahwa 20 tahun mendatang Asia Tenggara akan menjadi kawasan tercepat mengalami pertumbuhan di bidang pariwisata. Sekretaris UNWTO. Asean merupakan wilayah yang cukup diminati wisatawan dunia. Asia Tenggara menyumbang 7,5-8\% pertumbuhan pariwisata dunia. Jadi 74-75 juta orang mengunjungi kawasan ini dalam 1 tahun (http://www2.unwto.org, diakses 17 September 2018).

Mantan Menteri Pariwisata dan Ekonomi Kreatif Mari Elka Pangestu dalam ASEAN Tourism Forum (ATF) dan Travel Exhibition (Travex) 2012, mengatakan bahwa Pemerintah memberikan Free Duty Import bagi investor yang tertarik membangun infrastruktur suatu destinasi pariwisata. Dengan demikian peluang dan potensi pariwisata Indonesia akan terus berkembang dan memiliki kesempatan besar dalam peningkatan jumlah kunjungan wisatawan.

Pariwisata menjadi salah satu sektor utama penghasil devisa pemerintah Indonesia. SWA Magazine edisi XXVIII (2012) menyatakan bahwa pariwisata berpeluang sebagai bisnis yang akan berkembang pesat di tahun 2012, sehingga Indonesia mentargetkan jumlah kunjungan wisatawan mencapai 8 juta orang dengan target devisa US\$ 8,98 milliar. Peningkatan jumlah wisatawan mancanegara (wisman) akan berpengaruh pada perkembangan bisnis biro perjalanan wisata dan pertumbuhan bisnis perhotelan.

World Tourism Organization pada tahun 2002 mempredisikan pertumbuhan pariwisata di beberapa negara di dunia dan mengidentifikasi 10 top segmen pasar dalam dunia pariwisata yaitu (1). Sun and beach tourism, (2). Sport tourism, (3). Adventure tourism, (4). Nature based tourism, (5). cultural tourism, (6). Urban tourism, (7). Rural tourism, (8). Cruises, (9). Theme park, (10). Meeting and conference.

Pariwisata merupakan salah satu dari industri gaya baru, yang mampu menyediakan pertumbuhan ekonomi yang cepat dalam hal kesempatan kerja , pendapatan, taraf hidup dan dalam mengaktifkan sektor produksi lain di dalam negara penerima wisatawan ( Harris, Keer, Foster Ceylon dalam Wahab, 1988).

Candi Borobudur Jawa Tengah merupakan salah satu dari sepuluh destinasi wisata yang telah ditetapkan oleh pemerintah berdasarkan keputusan penetapan 10 destinasi prioritas yang merupakan amanat Presiden (Surat Sekretariat Kabinet Nomor B 652/Seskab/Maritim/2015 tanggal 6 November 2015)

Candi Borobudur merupakan candi Buddha terbesar di dunia yang menjadi salah satu keajaiban dunia. Candi yang dibangun oleh Raja Samaratungga dari dinasti Syailendra pada abad ke-8 ini kini telah dikelilingi berbagai taman wisata dengan berjuta keindahannya. Terletak di Desa Borobudur, Kecamatan Borobudur, 40 km dari 
Yogyakarta, Candi Borobudur akan menjadi prioritas kunjungan wisatawan di tahun 2016.

Penelitian ini mengacu pada persepsi dan ekspekstasi antara wisatawan mancanegara dan wisatawan nusantara terhadap kualitas jasa di Candi Borobudur Jawa Tengah. Penelitian ini diharapkan dapat dijadikan referensi manajemen Taman Wisata Candi (PT TWC) khususnya dan pemerintah dalam hal ini Kementerian Pariwisata Republik Indonesia sebagai bahan evaluasi ditetapkannya Candi Borobudur sebagai salah satu destinasi unggulan yang diharapkan dapat menyedot wisatawan mancanegara.

Seperti telah kita ketahui bahwa geliat sektor pariwisata semakin tahun semakin menunjukkan perkembangan dalam kontribusinya sebagai penghasil devisa. Seperti saat ini saja sektor pariwisata telah menduduki rangking ke 4 perolehan devisa, dan kedepan perlu ditingkatkan lagi menjadi rangking lebih baik (Marianti, M., 2019; Rahmalina, W, 2019; Nur, I., \& Mariantha, I. N, 2018; Ardiansyah, A., \& Sutedjo, A., 2019).

Sektor pariwisata di Indonesia cukup menggembirakan khususnya potensi destinasi alam dan sejarah, kini tinggal pengelolaan dan dukungan dari sektor lain sepertihalnya sektor perhubungan sebagai sarana aksesibilitas dan diversifikasi produk daya tarik wisata. Upaya peningkatan wisatawan mancanegara berkaitan dengan daya tarik wisata perlu dimaknai tentang bagaimana sikap wisatawan mancanegara dalam mempersepsikan dan ekspektasinya sehingga menjadi titik sentral yang lebih terukur ketika ingin mendongkrak devisa negara dari sektor pariwisata.

Berdasarkan latar belakang di atas maka dalam penelitian ini dirumuskan berbagai masalah penelitian sebagai berikut : (1) Apakah terdapat perbedaan persepsi antara wisatawan nusantara dengan wisatawan mancanegara terhadap kualitas jasa di Candi Borobudur Jawa Tengah? (2) Apakah terdapat perbedaan ekspektasi antara wisatawan nusantara dengan wisatawan mancanegara terhadap kualitas jasa di Candi Borobudur Jawa Tengah?

Serangkaian hasil penelitian ini diharapkan dapat bermanfaat bagi berbagai pihak antara lain: (1) Kementerian Pariwisata Republik Indonesia sebagai bahan masukan dan kajian tentang perilaku dan tanggapan wisatawan terhadap obyek wisata Candi Borobudur sebagai bagian dari destinsi utama yang ditetapkan oleh pemerintah dalam rangka mendongkrak perolehan devisa Negara; (2) Manajemen TWC Borobudur sebagai bagian dari evaluasi kinerja manajemen memberikan kepuasan yang sesungguhnya artinya sesuai dengan harapan wisatawan khususnya wisatawan mancanegara. Melalui penelitian ini akan dihasilkan perbedaan pandangan atau persepsi dan ekspektasi antara wisatawan lokal dan wisatawan mancanegara sehingga TWC dapat memberikan ketepatan dalam memberikan kepuasan kepada para pelanggan; (3) Pengembangan ilmu pengetahuan di dunia pemasaran obyek wisata sehingga dapat mengidentifikasi segmentasi pasar secara tepat. Melalui pengetahuan ini para marketer pariwisata dapat mengenali karaktristik wisatawan mancanegara melalui harapan yang diinginkan ketika berkunjung ke obyek wisata Candi Borobudur.

\section{LITERATUR REVIEW}

\section{Pengertian persepsi}

Definisi persepsi menurut Bimo Walgito, adalah suatu proses yang didahului oleh proses penginderaan, yaitu merupakan proses diterimanya stimulus oleh individu melalui alat indera atau juga disebut sensoris. Namun proses itu tidak berhenti begitu saja, melainkan stimulus tersebut diteruskan dan proses selanjutnya merupakan proses persepsi (2005). Sedangkan definisi persepsi menurut Simamora (2002) didefinisikan sebagai suatu proses dengan mana seseorang menyeleksi, mengorganisasikan dan menginterprestasi stimuti ke dalam suatu gambaran dunia yang 
berarti dan menyeluruh, dan persepsi terhadap kualitas jasa menurut Fandy Tjiptono (2006) adalah citra kualitas yang baik bukanlah berdasarkan sudut pandang pihak penyedia jasa, melainkan berdasarkan sudut pandang pelanggan.

Berdasarkan definisi di atas dapat diambil kesimpulan bahwa persepsi merupakan reaksi langsung atau tanggapan langsung seseorang melalui proses yang sifatnya kompleks dalam menerima dan menginterpretasikan suatu objek yang menggunakan alat indera sehingga persepsi dipengaruhi oleh faktor dari dalam dan faktor dari luar yang secara bersamaan menentukan persepsi seseorang.

Pengertian persepsi dalam hal ini adalah pengertian persepsi wisatawan, sehingga dapat disimpulkan bahwa persepsi wisatawan adalah pendapat wisatawan terhadap suatu objek tertentu yang diterima oleh wisatawan.

Persepsi terdiri atas beberapa unsur. Unsur-unsur tersebut meliputi: (1) Seleksi, unsur ini erat hubungannya dengan pengamatan atau stimulus yang diterima dari luar; (2) Interpretasi, yaitu proses pengorganisasian informasi sehingga mempunyai arti (3) Tingkah laku sebagai reaksi (Kamus Besar Bahasa Indonesia, 2002).

Proses seleksi ini terjadi pada saat seseorang memperoleh informasi yang selanjutnya akan berlangsungnya proses penyeleksian pesan yang dianggap penting dan tidak penting. Sedangkan interpretasi berlangsung ketika seseorang yang bersangkutan memberi tafsiran atau makna terhadap informasi tersebut secara menyeluruh.

Menurut Thoha (2003) proses pembentukan persepsi melalui beberapa tahap, yaitu sebagai berikut:

1. Stimulus (rangsangan) atau situasi yang hadir

Awal terjadinya persepsi dimulai ketika seseorang dihadapkan dengan situasi atau situasi stimulus. Situasi yang dihadapi itu mungkin bisa berupa stimulus penginderaaan dekat dan langsung atau beberapa bentuk lingkungan sosiokultur dan fisik yang menyeluruh.

2. Registrasi

Dalam masa registrasi suatu gejala yang Nampak adalah mekanisme fisik yang berupa penginderaan dan seseorang yang terpengaruh, kemampuan fisik untuk mendengar dan melihat akan mempengaruhi persepsi. Dalam hal ini seseorang mendengar atau melihat informasi yang terkirim kepadanya.

3. Interpretasi

Merupakan suatu proses kognitif dari persepsi yang amat penting. Proses interpretasi ini tergantung pada cara pendalaman, motivasi, dan kepribadian seseorang. Pendalaman, motivasi, dan kepribadian seseorang itu akan berbeda dengan orang lain. Dan disinilah letak sumber perbedaan pertama dari persepsi.

4. Umpan Balik

Setelah melalui proses interpretasi kemudian dipersepsikan oleh seseorang dalam bentuk umpan balik. Umpan balik yang diberikan antara orang yang satu dengan yang lain akan berbeda tergantung dari interpretasi (penafsiran) yang merekaalami (Thoha, 2003).

Berdasarkan pendapat tersebut maka dapat disimpulkan bahwa dalam proses timbulnya persepsi terjadi melalui beberapa tahap. Tahap pertama adalah seleksi, dimana seseorang memilih objek atau informasi yang menjadi perhatian utamanya. Tahap kedua adalah interpretasi, yaitu proses mengorganisir informasi, sehingga informasi objek tersebut mempunyai arti bagi seseorang. Dan tahap ketiga adalah memberikan reaksi pada interpretasi tersebut dalam tingkah laku.

Menurut Bimo Walgito (2005) faktorfaktor yang berperan dalam persepsi antara lain:

1. Objek yang diteliti

Objek menimbulkan stimulus yang mengenai alat indera atau reseptor. Stimulus dapat datang dari luar individu yang mempersepsi, tetapi juga dapat 
datang dari dalam diri individu yang bersangkutan yang langsung mengenai syaraf penerima yang bekerja sebagai reseptor. Namun sebagian terbesar stimulus datang dari luar individu.

2. Alat indera, syaraf, dan pusat susunan syaraf

Alat indera atau reseptor merupakan alat untuk menerima stimulus. Di samping itu juga harus ada syaraf sensoris sebagai alat untuk meneruskan stimulus yang diterima reseptor ke pusat susunan syaraf, yaitu otak sebagai pusat kesadaran. Sebagai alat untuk mengadakan respon diperlukan syaraf motoris.

3. Perhatian

Untuk menyadari atau untuk mengadakan persepsi diperlukan adanya perhatian, yaitu merupakan langkah pertama sebagai suatu persiapan dalam rangka mengadakan persepsi. Perhatian merupakan pemusatan atau konsentrasi dari seluruh aktivitas individu yang ditujukan kepada sesuatu atau sekumpulan objek.

\section{Ekspektasi}

Robert Kreitner dan Angelo Kinicki (2003) mengungkapkan mengenai teori harapan sebagai bentuk motivasi untuk berperilaku yang menghasilkan kombinasi keinginan yang diharapkan sebagai hasil. Persepsi memainkan peran inti dalam teori harapan karena persepsi menekankan kemampuan kognitif untuk mengantisipasi konsekuensi perilaku yang cenderung terjadi.

Fotiadis dkk., (2018) mengungkapkan teori harapan pelanggan sebagai bentuk keyakinan pelanggan sebelum mencoba atau membeli suatu produk, yang dijadikan standar atau acuan dalam menilai kinerja produk tersebut. Meskipun demikian, dalam beberapa hal belum tercapai kesepakatan, misalnya mengenai sifat standar harapan yang spesifik, jumlah standar yang digunakan, maupun sumber harapan.
Menurut Rivo dalam Mutia (2006) ekspektasi atau harapan konsumen memiliki peranan yang sangat besar sebagai suatu standar perbandingan dalam evaluasi kualitas maupun kepuasan. Harapan konsumen merupakan keyakinan konsumen sebelum mencoba atau membeli suatu produk yang dijadikan standar acuan dalam menilai kinerja produk tersebut.

Adapun pendapat Kartolo dan Gulo dalam Mutia (2006) menyatakan bahwa harapan adalah kecondongan yang dipelajari, dimana suatu organisme dapat memperkirakan bahwa situasi tertentu akan timbul dengan memberi respon atau tanggapan tertentu terhadap rangsangan atau stimulus.

Menurut Fandy Tjiptono (2006) ada beberapa faktor yang mempengaruhi harapan konsumen terhadap kualitas jasa, faktor-faktor tersebut antara lain:

1. Enduring Service Intensifiers

Faktor ini merupakan faktor yang stabil dan mendorong konsumen untuk meningkatkan sensitifitasnya terhadap jasa. Faktor ini meliputi harapan yang disebabkan oleh orang lain dan filosofi seseorang mengenai jasa. Kebutuhan mendasar yang dirasakan oleh seseorang dan juga sangat menentukan harapannya. Kebutuhan ini meliputi kebutuhan fisik dan psikologis.

2. Transitory Service Intensifiers

Faktor ini merupakan faktor individual yang bersifat sementarayang meningkatkan sensivitas pelanggan terhadap jasa.

3. Perceived service alternatives

Faktor ini merupakan persepsi pelanggan terhadap tingkat atau derajat pelayanan perusahaan lain yang sejenis. Bila konsumen mempunyai alternatif lain maka tingkat harapan terhadap suatu jasa akan meningkat.

4. Self-perceived service role

Faktor ini adalah persepsi pelanggan terhadap tingkat atau derajat 
keterlibatannya dalam mempengaruhi jasa yang diterimanya. Apabila konsumen terlibat dalam proses penyampaian jasa dan jasa yang terjadi ternyata tidak begitu baik, maka pelanggan tidak bisa menimpakan kesalahan sepenuhnya kepada penyedia jasa.

5. Situational Factors

Faktor situsional terdiri atas segala kemungkinan yang bisa mempengaruhi kinerja jasa yang berada di luar kendai penyedia jasa.

6. Explicit services promises

Faktor ini merupakan pernyataan oleh organisasi tentang jasanya kepada konsumen. Bisa dalam bentuk iklan, komunikasi dengan karyawan organisasi atau personal selling.

7. Implicit services promise

Faktor ini menyangkut petunjuk yang berkaitan dengan jasa, yang memberikan kesimpulan bagi pelanggan tentang jasa yang bagaimana yang seharusnya dan yang akan diberikan.

8. Word of mouth

Merupakan pernyataan yang disampaikan oleh orang lain selain organisasi kepada pelanggan

9. Past experience

Merupakan pengalaman masa lampau yang meliputi hal-hal yang telah dipelajari atau diketahui pelanggan dari yang telah diterimanya di masa lampau. Harapan pelanggan dari waktu ke waktu akan terus berkembang seiring dengan semakin banyaknya informasi yang diterimanya.

\section{Pelayanan (Service)}

Kotler \& Makens (2002) memberi batasan tentang pelayanan/ service sebagai suatu aktivitas yang memberikan manfaat, yang ditawarkan oleh satu pihak kepada pihak lain dalam bentuk tidak nyata (intangible) dan tidak menimbulkan perpindahan kepemilikan.

Zeithaml dan Bitner (1996) memberi batasan tentang pelayanan/ service sebagai berikut :
"Service is include all economic activities whose output is not a physical product or contraction is generally consumed at that time it is produced and provides added value in forms (such as conveniencef amusementf confort or health".

Jika diartikan secara bebas, pelayanan memiliki makna sebagai bentuk aktiftas ekonomi yang hasilnya bukan merupakan produk dalam bentuk fsik, atau berupa kontruksi atau barang, yang biasa dikonsumsi pada saat yang bersamaan dengan waktu produksi sambil memberikan nilai tambah misalnya kenyamanan, hiburan, kesenangan, atau kesehatan (Hermawan, H dkk., 2018).

Menurut teori beberapa ahli, pelanggan menilai kualitas pelayanan melalui 5 dimensidimensi pelayanan sebagai tolok ukurnya. Lima dimensi tersebut diantaranya :

1. Reliabilitas (realibility) ,adalah kemampuan untuk memberikan secara tepat dan benar jenis pelayanan sesuai yang telah dijanjikan kepada pelanggan.

2. Responsif (Responsiveness), yaitu kesadaran atau keinginan untuk bertindak capat dalam membantu pelanggan dan memberikan pelayanan tepat waktu.

3. Kepastian atau jaminan (Assurance), adalah pengetahuan dan kesopan santunan serta kepercayaan diri pegawai.

4. Empati (Empathy), memberikan perhatian individu kepada tamu secara khusus. Dimensi empati memiliki ciri-ciri sebagai berikut: adanya kemauan untuk melakukan pendekatan, adanya perlindungan dan usaha untuk mengerti keinginan, kebutuhan, dan perasaan tamu.

5. Nyata (Tangibles) yaitu sesuatu yang Nampak atau yang nyata yaitu: penampilan para pegawai yang rapi, fasilitas peralatan yang bersih dan sehat, peralatan fasilitas penunjang yang berfungsi baik dan lain sebagainya (Zeithaml \& Bitner, 1996 dan Hermawan, H dkk., 2018).

Selain lima dimensi diatas, dalam penilaian kualitas pelayanan juga dapat 
mempertimbangkan variable lainya seperti : (1) Kemampuan akses (Access) kemampuan pendekatan dan kontak mata; (2) Kesopanan, rasa hormat, pertimbangan dan keramahan personil kontak pelanggan;

Communication, menjaga informasi dalam bahasa mereka dapat memahami;

Keamanan, kebebasan dari risiko, bahaya atau diragukan; (5) Memahami/mengetahui pelanggan membuat upaya untuk mengetahui kebutuhan pelanggan (Parasuraman dkk., dalam Saleh \& Ryan, 1991; dan Zeithaml \& Bitner, 1996).

\section{METODE}

Artikel ini mencoba untuk mendiskusikan tentang perbedaan persepsi dan harapan wisatawan lokal atau sering disebut wisatawan Nusantara (wisnus) dengan wisatawan asing atau wisatawan mancanegara (wisman) terhadap kualitas layanan di Candi Borobudur.

Penelitian telah dilaksanakan pada tanggal pada tanggal 23 Maret 2018 sampai 25 Juni 2018. Jumlah partisipan dalam riset sebanyak 96 wisatawan yang terdiri dari 48 wisatawan mancanegara (wisman) dan 48 wisatawan Nusantara (wisnus), pemilihan partisipan dilakukan dengan metode purposive sampling. Data dicari dengan menggunakan kuesionair terkait dengan fenomena yang diteliti yaitu persepsi dan harapan wisatawan terhadap pelayanan di Candi Borobudur. Sedangkan analisis data dilakukan dengan metode desktiptif kuantitatif.

\section{HASIL DAN PEMBAHASAN}

\section{Deskripsi Objek Penelitian}

Candi borobudur adalah salah satu peninggalan sejarah agama buddha. Candi borobudur didirikan oleh penganut agama Buddha Mahayana yang diperkirakan berdiri tahun 800 masehi pada masa pemerintahan Wangsa Syailendra. Tetapi berdasarkan prasasti Kayumwungan 26 Mei 824, bahwa
Candi Borobudur didirikan oleh Raja Samaratungga pada abad ke-8 hingga ke-9. Proses pembangunannya sendiri menghabiskan waktu 75 tahun di bawah kepimpinan seorang arsitek yang bernama Gunadharma. Dalam pembangunannya Gunadharma sudah dapat menerapkan konsep interlock terhadap batu andesit yang mencapai 2.000 .000 balok batu.

Candi Borobudur merupakan candi atau kuil terbesar di dunia dan juga merupakan salah satu monument terbesar di dunia. Candi Borobudur terdiri atas 6 teras yang berbentuk bujur sangkar yang diatasnya terdapat tiga pelataran melingkar. Di dinding candinya dipahatkan 2672 panel relief dan terdapat juga 504 buah arca Budha yang menghiasi Candi Borobudur. Relief yang terpahat didinding merupakan susunan dari 4 kisah utama, yaitu: Karmawibangga, Lalita Wistara, JatakaAwadana, dan Gandawyuda. Selain bercerita tentang perjalanan Budha, relief yang ada juga bercerita tentang kemajuan masyarakat Jawa pada masa itu.

Borobudur merupakan mahakarya seni rupa Buddha Indonesia, sebagai contoh puncak pencapaian keselarasan teknik arsitektur dan estetika seni rupa Buddha di Jawa. Bangunan ini diilhami gagasan dharma dari India, antara lain stupa, dan mandala, tetapi dipercaya juga merupakan kelanjutan unsur lokal; struktur megalitik punden berundak atau piramida bertingkat yang ditemukan dari periode prasejarah Indonesia. Sebagai perpaduan antara pemujaan leluhur asli Indonesia dan perjuangan mencapai Nirwana dalam ajaran Budha.

Pada hakikatnya Borobudur adalah sebuah stupa yang bila dilihat dari atas membentuk pola Mandala Besar. Mandala adalah pola rumit yang tersusun atas bujursangkar dan lingkaran konsentris yang melambangkan kosmos atau alam semesta yang lazim ditemukan dalam Buddha aliran Wajrayana-Mahayana. Sepuluh pelataran yang dimiliki Borobudur menggambarkan secara jelas filsafat mazhab Mahayana yang secara 
bersamaan menggambarkan kosmologi yaitu konsep alam semesta, sekaligus tingkatan alam pikiran dalam ajaran Buddha. Bagaikan sebuah kitab, Borobudur menggambarkan sepuluh tingkatan Bodhisattva yang harus dilalui untuk mencapai kesempurnaan menjadi Buddha. Dasar denah bujur sangkar berukuran 123 meter pada tiap sisinya. Bangunan ini memiliki sembilan teras, enam teras terbawah berbentuk bujur sangkar dan tiga teras teratas berbentuk lingkaran.

Pola Mandala dari bangunan Candi Borobudur mencerminkan alam semesta dalam kepercayaan Buddha. Struktur bangunan ini berbentuk kotak dengan empat pintu masuk dan titik pusat berbentuk lingkaran. Jika dilihat dari luar hingga ke dalam terbagi menjadi dua bagian yaitu alam dunia yang terbagi menjadi tiga zona di bagian luar, dan alam Nirwana di bagian pusat. Adapun 3 zona dari bagian alam dunia meliputi:

1. Zona Kamadhatu

Zona Kamadhatu yang terdapat pada bagian kaki Borobudur menggambarkan alam dunia yang terlihat dan sedang dialami oleh manusia sekarang. Dimana dunia masih dikuasai oleh kama atau "nafsu rendah". Bagian ini sebagian besar tertutup oleh tumpukan batu (struktur tambahan) yang diduga dibuat untuk memperkuat konstruksi candi. Pada bagian kaki asli yang tertutup struktur tambahan ini terdapat 160 panel cerita Karmawibhangga sutra, yang menjelaskan hukum sebab akibat. Menggambarkan mengenai sifat dan nafsu manusia, seperti merampok, membunuh, memperkosa, penyiksaan, dan fitnah. Sekarang tudung penutup pada bagian dasar telah dibuka secara permanen agar pengunjung dapat melihat relief yang tersembunyi di bagian bawah.

2. Zona Rupadhatu

Zona Rupadhatu adalah alam peralihan, dimana manusia telah dibebaskan dari urusan dunia. Rupadhatu terdiri dari empat lorong dengan 1.300 gambar relief. Panjang relief seluruhnya $2,5 \mathrm{~km}$ dengan 1.212 panel berukir dekoratif. Rupadhatu adalah dunia yang sudah dapat membebaskan diri dari nafsu, tetapi masih terikat oleh rupa dan bentuk. Tingkatan ini melambangkan alam antara yakni, antara alam bawah dan alam atas. Pada bagian Rupadhatu ini patung-patung Buddha terdapat pada ceruk atau relung dinding di atas pagar langkan atau selasar. Terdapat 328 arca Budha (aslinya terdapat 432 arca Buddha) di dalam relung-relung terbuka di sepanjang sisi luar di pagar langkan. Pada pagar langkan terdapat sedikit perbedaan rancangan yang melambangkan peralihan dari ranah Kamadhatu menuju ranah Rupadhatu; pagar langkan paling rendah dimahkotai ratna, sedangkan empat tingkat pagar langkan diatasnya dimahkotai stupika (stupa kecil). Bagian teras-teras yang berbentuk bujursangkar ini kaya akan hiasan dan ukiran relief.

3. Zona Arupadhatu

Zona Arupadhatu adalah alam tertinggi, rumah Tuhan. Berbeda dengan loronglorong Rupadhatu yang kaya akan relief, mulai lantai kelima hingga ketujuh dindingnya tidak berelief. Denah lantai berbentuk lingkaran. Tingkatan ini melambangkan alam atas, di mana manusia sudah bebas dari segala keinginan dan ikatan bentuk dan rupa, namun belum mencapai nirwana. Pada pelataran lingkaran terdapat 72 dua stupa kecil berterawang yang tersusun dalam tiga barisan yang mengelilingi satu stupa besar sebagai stupa induk. Stupa kecil berbentuk lonceng ini disusun dalam 3 teras lingkaran yang masing-masing berjumlah 32, 24, dan 16 (total 72 stupa). Dua teras terbawah stupanya lebih besar dengan lubang berbentuk belah ketupat, satu teras teratas stupanya sedikit lebih kecil dan lubangnya berbentuk kotak bujur sangkar. 
Patung-patung Buddha ditempatkan di dalam stupa yang ditutup berlubanglubang seperti dalam kurungan. Dari luar patung-patung itu masih tampak samarsamar.

Rancang bangun ini dengan cerdas menjelaskan konsep peralihan menuju keadaan tanpa wujud, yakni arca Buddha itu ada tetapi tak terlihat. Tiga serambi berbentuk lingkaran mengarah ke kubah di bagian pusat atau stupa yang menggambarkan kebangkitan dari dunia. Pada bagian ini tidak ada ornamen maupun hiasan, yang berarti menggambarkan kemurnian tertinggi. Serambi pada bagian ini terdiri dari stupa berbentuk lingkaran yang berlubang, lonceng terbalik, berisi patung Buddha yang mengarah ke bagian luar candi.

\section{Pengelolaan Candi Borobudur}

Pengelolaan Candi Borobusur dilakukan oleh PT Taman Wisata Candi Borobudur, Prambanan dan Ratu Boko (Persero). PT TWC Borobudur, Prambanan dan Ratu

Boko (Persero) adalah salah satu Badan Usaha Milik Negara (BUMN) yang bergerak di bidang pariwisata. Nama BUMN ini lebih sering disingkat menjadi PT. Taman. Sesuai dengan namanya, BUMN ini mengelola pariwisata di tiga kawasan destinasi wisata yaitu Candi Borobudur di Magelang, Jawa Tengah, Candi Prambanan dan Komplek Ratu Boko di Sleman, Yogyakarta. BUMN ini merupakan salah satu BUMN yang komposisi kepemilikan sahamnya $100 \%$ milik Pemerintah Republik Indonesia. Selain ketiga cagar budaya tersebut, BUMN ini juga mengelola Hotel Manohara di Kawasan Strategis Nasional Borobudur dan Sendratari Ramayana di Kawasan Candi Prambanan.

PT. Taman Wisata Candi Borobudur, Prambanan \& Ratu Boko (Persero) pada awalnya berdiri dengan nama PT. Taman Wisata Candi Borobudur \& Prambanan (Persero) berdasarkan PP Nomor 7 Tahun 1980 dengan Akta Notaris Soeleman Ardjasasmita, SH, Nomor: 19 tanggal 15 Juli 1980. BUMN ini diberi kewenangan penuh untuk mengelola kedua taman wisata tersebut berdasarkan Keputusan Presiden Republik Indonesia Nomor: 1 tahun 1992 tentang Pengelolaan Taman Wisata Candi Borobudur, Prambanan, serta Pengendalian Lingkungannya.Dalam perkembangannya, Kawasan Ratu Boko menjadi bagian dari taman wisata sehingga nama perusahaan ini harus diubah. Sesuai Akta Notaris Soekeimi, SH, Nomor: 25 tanggal 3 Agustus 1994, nama BUMN ini menjadi PT Taman Wisata Candi Borobudur Prambanan \& Ratu Boko (Persero).

Tujuan pendirian BUMN ini adalah mengelola pariwisata di lingkungan Candi Borobudur, Candi Prambanan, dan Keraton Ratu Boko serta peninggalan sejarah dan purbakala lainnya. Perusahaan ini mengupayakan ketiga destinasi wisata tersebut menjadi taman wisata yang bersifat kultural, edukatif, dan rekreatif. Perusahaan juga berkewajiban mengoptimalkan pemanfaatan sumberdaya yang dimiliki untuk menghasilkan barang dan atau jasa yang bermutu tinggi dan berdaya saing kuat. Sebagai badan usaha yang turut melaksanakan dan menunjang kebijakan dan program pemerintah di bidang ekonomi dan pembangunan nasional, PT. TWC Candi Borobudur, Prambanan dan Ratu Boko juga dituntut menghasilkan laba guna meningkatkan nilai perusahaan dan devisa negara. Untuk mencapai tujuannya, perusahaan ini diberi kewenangan untuk merencanakan, mengembangkan dan memanfaatkan jasa-jasa, prasarana, sarana dan fasilitas umum lainnya di lingkungan Taman Wisata Candi untuk kegiatan pariwisata. PT. TWC Borobudur, Prambanan dan Ratu Boko memiliki dua visi yaitu:

1. Untuk menjalankan kedua visi tersebut, BUMN ini memiliki misi sebagai berikut: Menjadi BUMN yang unggul, memiliki pengelolaan yang bersih dan mengembangkan pariwisata yang selaras 
dengan pelestarian warisan budaya bangsa.

2. Menjadikan Borobudur,Prambanan dan Kawasan Ratu Boko sebagai Destinasi Wisata Budaya Kelas Dunia.

Untuk menjalankan kedua visi tersebut, BUMN ini memiliki misi sebagai berikut:

1. Mengelola lingkungan dan menyelaraskan upaya pelestarian taman sekitar Candi Borobudur, Prambanan dan Ratu Boko dan Cagar Budaya lain.

2. Mengembangkan Sustainable

Tourism dengan cara mengembangkan industri pariwisata dan berbagai pendukungnya seperti pengembangan usaha jasa transportasi wisata, usaha jasa akomodasi dan restoran, serta usaha pertunjukan sendratari Ramayana.

3. Mengkampanyekan nilai-nilai luhur Cagar Budaya melalui pemutaran film pada ruang Audio Visual, Museum dan Perpustakaan.

4. Memberikan pelayanan wisata budaya yang berkualitas tinggi dan menyediakan fasilitas penunjang. Hingga saat ini, fasilitas penunjang yang dapat dimanfaatkan oleh pengunjung adalah Parkir Kendaraan, Pusat Informasi, Audio Visual, Museum, Perkiosan, Arena Bermain Anak, dan Angkutan Taman.

5. Menumbuhkan perekonomian masyarakat di sekitar lingkungan Cagar Budaya melalui pengembangan industri kerakyatan atau industri rumahan (home industry) seperti mendukung pengembangan kerajinan lokal, produk khas, asesoris, dan lain-lain.

\section{Analisis Penilaian Responden terhadap Variabel Persepsi dan Ekspektasi}

Untuk aspek reliability, persepsi maupun ekspektasi wisatawan yang berkaitan dengan; pelayanan petugas TWCB baik penampilan, penyampaian informasi, maupun berbagai kejelasan dalam memberikan petunjuk pada wisatawan terjadi perbedaan yang cukup mencolok pada variabel persepsi penilaian positif wisman dan wisnus. Wisman menyatakan bahwa $43.75 \%$ sangat bagus, sedangkan wisnus hanya sebesar $29.17 \%$. Sedangkan penilaian negatif sebanyak $43.75 \%$ menyatakan kurang baik untuk wisnus dan hanya sebesar 12.5 dari wisman yang menyatakan kurang baik.

Aspek reliability, ekspektasi wisatawan dari penilaian positif kedua wisatawan tidak jauh berbeda tetapi dari penilain negatif ekspektasi wisnus cukup besar yaitu $50 \%$ atau separoh dari responden penelitian menyatakan kurang baik sedangkan dari kalangan wisman hanya sebesar $31.25 \%$ saja.

Untuk aspek responsiveness, persepsi maupun ekspektasi wisatwan yang berkaitan dengan; kepekaan karyawan, daya tanggap terhadap wisatawan dan manivestasi komitmen atau realisasi janji-janji TWCB terhadap wisatawan dari penilaian positif tidak menunjukkan perbedaan yang berarti baik pada variabel persepsi maupun variabel ekspektasi antara wisman dan winus pada dasarnya kedua kelompok wisatawan menyatakan sangat baik. Tetapi dari penilaian negatif baik pada variabel persepsi maupun ekspektasi wisnus terjadi cukup fantastis yaitu $39.58 \%$ untuk variabel persepsi dan $29.17 \%$ untuk variabel ekspektasi.

Untuk aspek competence, persepsi wisatawan yang berkaitan dengan ; kepemilikan ketrampilan dana pengetahuan, pengalaman, keprofesionalan dan partisipasi kepelatihan karyawan yang ada di TWCB relatif sama. Perbedaan terjadi pada variabel ekspektasi dimana wisnus menilai bahwa sebesar $37.5 \%$ menyaakan tidak puas atau memberikan penilaian kurang baik. Sedangkan wisman menyatakan bahwa demensi competence karywan TWCB cukup bagus bahkan sangat bagus sebesar $33.34 \%$

Untuk aspek access, persepsi wisatawan maupun ekspektasi yang berkaitan dengan ; kemudahan menghubungi manajemen, kemudahan menjangkau destinasi melalui 
berbagai moda transportasi dan kemudahan mengakses informasi destinasi melalui teknologi, baik variabel persepsi maupun variabel ekspektasi untuk wisnus menyatakan ketidakpuasannya atau memberikan penilaian kurang baik hal ini diduga karena tidak hanya transportasi umum yang bisa mengakses wisatawan sampai ke destinasi wisata cukup besar yaitu $37.5 \%$ baik untuk variabel persepsi maupun ekspektasi.

Untuk aspek courtesy, persepsi wisatawan maupun ekspektasi yang berkaitan dengan; sikap sopaan satun, respek terhadap wisatawan dalam hal kebutuhan dan keinginannya. Baik wisman maupun wisnus mmberikan penilai positip terhadap kedua variabel yaitu persepsi mauun ekspektasi $35.42 \%, 33.34 \%, 22.92 \%$ dan 20.84\%. Dengan demikian wisman maupun wisnus memiliki persepsi dan ekpektasi yang relative sama terhadap sikap dan perhatian petugas terhadap pengunjung di TWCB.

Untuk aspek communication, persepsi wisatawan maupun ekspektasi yang berkaitan dengan; kejelasan penyampaian informasi, perhatian terhadap keluhan, penguasaan bahasa asing dan penyediaan median informasi. Baik wisman maupun wisnus tidak memiliki penilaian negatif. Artinya baik dari variabel ekspektasi maupun variabel persepsi aspek communication pihak manajemen TWCB semuanya baik dan cukup baik. Dari variabel persepsi penilaian wisman $43.75 \%$ dan $62 . \%$ wisnus menilai bahwa aspek komunikasi cukup baik, sedangkan dari variabel ekspektasi $22.91 \%$ untuk wisman dan $58.34 \%$ untuk wisnus menilai baik penilaian terhadap aspek komunikasi manajemen dengan wisatawan.

Untuk aspek credibility, persepsi wisatwan maupun ekspektasi yang berkaitan dengan; komitmen TWCB terhadap resiko kecelakaan wisatawan, ada interaksi positip, kepribadian karyawan, dan tanggungjawab TWCB sesuai janji. Dari variabel persepsi penilaian wisman dan wisnus relative sama artinya baik wisman maupun wisnus menilai bahwa komitmen dan terjadinya interkai positif antara manajemen dengan wisatawan cukup baik dan sangat baik. Tetapi pada variabel ekspektasi ada sebanyak $22.92 \%$ wisman menyatakan tisak sesuai atau tidak ada komitmen di dalam manajemen TWCB dan kurangnya interkasi yang positif antara manajemen dengan perusahaan.

Untuk aspek security persepsi wisatawan maupun ekspektasi yang berkaitan dengan; keterjaminan keamanan baik keamanan fisik maupun gangguan pencurian. Baik wisman maupun wisnus tidak memiliki penilaian negatif. Artinya baik dari variabel ekspektasi maupun variabel persepsi aspek security mendapatkan penailan cukup baik dan baik diatas $70 \%$ responden penelitian. Hal ini menunjukkan bahwa pada aspek keamanan manajemen TWCB sudah bisa menjamin keamanan wisatawan saat berkunjung ke obyek wisata.

Untuk aspek knowing the customer, persepsi wisatawan maupun ekspektasi yang berkaitan dengan; penyampaian informasi halhal yang baru bagi wisatawan baik secara langsung maupun melalui media dan berbagai upaya manajemen dalam memenuhi keinginan wisatawan. Dari hasil pendapat responden pada varibel persepsi terdapat perbedaan yang cukup mencolok yaitu untuk wisman cenderung memberikan nilai negatif sebesar $35.83 \%$ sedangkan pada wisnus hanya sebesar $12.49 \%$. Hal ini sangat mungkin terjadi karena perhatian wisnus tidak terlalu kesulitan dalam melakukan komunikasi dengan karyawan, lain halnya dengan wisman yang sering terkendala persoalan bahasa. Pada variabel ekspektasi relatif tidak ada perbedaan kedua jenis wisatawan memberikan nilai positif atau menyatakan puas sesuai dengan harapan mereka.

Untuk aspek tangible, persepsi wisatawan maupun ekspektasi yang berkaitan dengan; tersedianya fasilitas kamar kecil, tersedianya fasilitas bagi penyandang difabel, keberadaan restoran, tempat parkir, fasilitas bermain. Baik wisman maupun wisnus memberikan penilaian 
cenderung negatif. Dari variabel persepsi wisman sebesar 39, 55\% dan 31,24\% dari variabel ekspektasi penyatakan tidak puas atau memberikan penilaian tidak baik, sedangkan untuk wisnus dari variabel persepsi sebesar $10.41 \%$ dan $60.41 \%$ dari variabel ekspektasi juga meyatakan kurang puas atas keberadaan aspek tangible. Hal ini dapat dinyatakan bahwa terjadi perbedaan ekspektasi dan persepsi dikalangan wisnus, ditunjukkan bahwa keberadaan restoran yang cukup jauh dari obyek, tidak adanya fasilitas khusus untuk penyandang difabel maupun wisatawan usia lanjut.

\section{SIMPULAN}

Dari hasil penelitian tentang perbedaan persepsi dan ekspektasi wisatawan nusantara dan wisatawan asing. Melalui studi eksplorasi dan penggunaan kuesioner sebagai instrumen penelitian dengan mengambil sebanyak 48 wisman dan 48 wisnus sebagai responden yang diukur melalui 10 aspek persepsi dan ekspektasi dapat diambil kesimpulan dan rekomendasi sebagai berikut :

Untuk aspek reliability, persepsi maupun ekspektasi wisatawan terjadi perbedaan yang cukup mencolok pada variabel persepsi penilaian positif wisman dan wisnus. Wisman menyatakan bahwa $43.75 \%$ sangat bagus, sedangkan wisnus hanya sebesar $29.17 \%$.

Untuk aspek responsiveness, persepsi maupun ekspektasi wisatawan dari penilaian positif tidak menunjukkan perbedaan yang berarti baik pada variabel persepsi maupun variabel ekspektasi antara wisman dan wisnus. Tetapi dari penilaian negatif baik pada variabel persepsi maupun ekspektasi wisnus terjadi cukup fantastis yaitu $39.58 \%$ untuk variabel persepsi dan $29.17 \%$ untuk variabel ekspektasi.

Untuk aspek competence, persepsi wisatwan relatif sama. Perbedaan terjadi pada variabel ekspektasi dimana wisnus menilai bahwa sebesar $37.5 \%$ menyatakan tidak puas. Sedangkan wisman menyatakan bahwa demensi competence karyawan TWCB cukup bagus bahkan sangat bagus sebesar 33.34\%

Untuk aspek access, persepsi wisatwan maupun ekspektasi baik variabel persepsi maupun variabel ekspektasi untuk wisnus menyatakan ketidakpuasannya hal ini diduga karena tidak aanya transportasi umum yang bisa mengakses wisatawan sampai ke destinasi wisata cukup besar yaitu $37.5 \%$ baik untuk variabel persepsi maupun ekspektasi.

Untuk aspek courtesy, persepsi wisatwan maupun ekspektasi baik wisman maupun wisnus memberikan penilai positif terhadap kedua variabel yaitu persepsi mauun ekspektasi $35.42 \%, 33.34 \%, 22.92 \%$ dan $20.84 \%$. Dengan demikian wisman maupun wisnus memiliki persepsi dan ekpektasi yang relative sama terhadap sikap dan perhatian petugas terhadap pengunjung di TWCB.

Untuk aspek communication, persepsi wisatawan maupun ekspektasi baik wisman maupun wisnus tidak memiliki penilaian negatif. Artinya baik dari variabel ekspektasi maupun variabel persepsi aspek communication pihak manajemen TWCB semuanya baik dan cukup baik. Dari variabel persepsi penilaian wisman $43.75 \%$ dan $62 . \%$ wisnus menilai bahwa aspek komunikasi cukup baik, sedangkan dari variabel ekspektasi $22.91 \%$ untuk wisman dan $58.34 \%$ untuk wisnus menilai baik penilaian terhadap aspek komunikasi manajemen dengan wisatawan.

Untuk aspek credibility, persepsi wisatwan maupun ekspektasi dari variabel persepsi penilaian wisman dan wisnus relative sama artinya baik wisman maupun wisnus menilai bahwa komitmen dan terjadinya interaksi positif antara manajemen dengan wisatawan cukup baik dan sangat baik. Tetapi pada variabel ekspektasi ada sebanyak $22.92 \%$ wisman menyatakan tidak sesuai atau tidak ada komitmen di dalam manajemen TWCB dan kurangnya interkasi yang positif antara manajemen dengan perusahaan.

Untuk aspek security persepsi wisatawan maupun ekspektasi baik wisman maupun wisnus tidak memiliki penilaian negatif. 
Artinya baik dari variabel ekspektasi maupun variabel persepsi aspek security mendapatkan penailan cukup baik dan baik diatas $70 \%$ responden penelitian. Hal ini menunjukkan bahwa pada aspek keamanan manajemen TWCB sudah bisa menjamin keamanan wisatawan saat berkunjung ke obyek wisata.

Untuk aspek knowing the customer, persepsi wisatawan maupun ekspektasi dari hasil pendapat responden pada varibel persepsi terdapat perbedaan yang cukup mencolok yaitu untuk wisman cenderung memberikan nilai negatif sebesar $35.83 \%$ sedangkan pada wisnus hanya sebesar $12.49 \%$. Hal ini sangat mungkin terjadi karena perhatian wisnus tidak terlalu kesulitan dalam melakukan komunikasi dengan karyawan, lain halnya dengan wisman yang sering terkendala persoalan bahasa. Pada variabel ekspektasi relatif tidak ada perbedaan kedua jenis wisatawan memberikan nilai positif atau menyatakan puas sesuai dengan harapan mereka.

Untuk aspek tangible, persepsi wisatawan maupun ekspektasi baik wisman maupun wisnus memberikan penilaian cenderung negatif. Dari variabel persepsi wisman sebesar $39,55 \%$ dan 31,24\% dari variabel ekspektasi penyatakan tidak puas atau memberikan penilaian tidak baik, sedangkan untuk wisnus dari variabel persepsi sebesar $10.41 \%$ dan $60.41 \%$ dari variabel ekspektasi juga meyatakan kurang puas atas keberadaan aspek tangible. Hal ini dapat dinyatakan bahwa terjadi perbedaan ekspektasi dan persepsi dikalangan wisnus, ditunjukkan bahwa keberadaan restoran yang cukup jauh dari obyek, tidak adanya fasilitas khusus untuk penyandang difabel maupun wisatawan usia lanjut.

Rekomendasi yang dapat disampaikan kepada manajemen TWCB adalah usahakan semaksimal mungkin menghilangkan kesenjangan perbedaan kepada kedua kelompok wisatawan dengan menentapkan Standard Operting Procedure (SOP) pada setiap departemen, dengan mengasumsikan bahwa kedua kelompok wistawan memiliki perilaku pembelian (customer behavior) yang sama.

\section{REFERENSI}

Ardiansyah, A., \& Sutedjo, A. (2019). Analisis Potensi Objek Wisata di Kabupaten Banyuwangi Selatan untuk Menjadi Pusat Pertumbuhan

Kepariwisataan. Swara Bhumi, 2(1).

Fotiadis, T., Abegglen, J. C., Stalk, G., Abell, D. F., Abernathy, W. J., Utterback, J. M., ... \& Ames, B. C. (2018). Environmental management: Revising the marketing perspective. In Strategic Marketing for High Technology Products: An Integrated Approach (Vol. 28, No. 3, pp. 1-40). Englewood Cliffs, NJ: John Wiley \& Sons.

Hermawan, H., Brahmanto, E., \& Hamzah, F. (2018). Pengantar Manajemen Hospitality. Pekalongan: Penerbit NEM

http://www2.unwto.org, diakses 17 September 2018

Kotler, P. (2002). Manajemen Pemasaranf terjemahan Hendra Teguhf edisi Milleniumf cetakan pertama (1st ed.). Jakarta: Prenhalindo.

Kreitner, Robert \& Kinicki, Angelo. (2003).

Perilaku Organisasi, Buku 1 Edisi

Kelima, (Erly Suandy. Terjemahan), Jakarta: Salemba Empat.

Marianti, M. (2019). Pengaruh Sarana Prasarana Pariwisata Terhadap Kepuasan Wisatawan Pada Objek Wisata Permandian Air Panas Lejja Di Kabupten Soppeng (Doctoral dissertation, Universitas Negeri Makassar).

Miftah, T. (2003). Perilaku Organisasi Konsep Dasar dan Aplikasinya. Grafindo Persada, Jakarta, 472. 
Mutia, R. (2009). Konsep Kurikulum, Ekspektasi, dan Persepsi. Makalah. (http://digilib.petra.ac.id/viewer.php?pag e=9\&qual=high\&submitval=next\&fname $=\% 2$ Fjiunkpe $\% 2 F s 1 \% 2 F h o t 1 \% 2 F 2006 \%$ 2Fjiunkpe-ns-s1-2006-33401131-6052ekspektasi-

chapter2.pdf\&submit. $x=13 \&$ submit. $y=2$ $\underline{2}$, diakses pada tanggal 10 Oktober 2012 pukul 13.05)

Nur, I., \& Mariantha, I. N. (2018, October). Implikasi Pengembangan Desa Wisata Terhadappeningkatan Ekonomi Masyarakat Lokal. In Prosiding Seminar Nasional: Manajemen, Akuntansi, dan Perbankan (Vol. 1, No. 1, pp. 10901104).

Rahmalina, W. (2019). Faktor Yang Mempengaruhi Promosi Dan Informasi Wisata Pulau Cinta. RABIT (Jurnal Teknologi dan Sistem Informasi Univrab), 4(1), 40-48.

Saleh, F., \& Ryan, C. (1991). Analysing service quality in the hospitality industry using the SERVQUAL model. Service Industries Journal, 11(3), 324-345.

Simamora, B. (2002). Panduan Riset Perilaku Konsumen, Jakarta: PT Gramedia Pustaka Utama.

Surat Sekretariat Kabinet Nomor B 652/Seskab/Maritim/2015 tanggal 6 November 2015

Tjiptono, F. (2006). Manajemen Jasa, Yogyakarta: C.V. Andi Offset (Penerbit Andi).

Walgito, B. (2005). Pengantar Psikologi Umum, Yogyakarta, C.V. Andi Offset.

Zeithaml, V. A., \& Bitner, M. J. (1996). Services Marketing. New York: Mc Graw Hill.

\section{PROFIL PENULIS}

Arif Dwi Saputra merupakan dosen Sekolah Tinggi Pariwisata AMPTA Yogyakarta yang memiliki fokus kajian dalam bidang manajemen kepariwisataan dan wisata budaya. Id Scholar :

https://scholar.google.co.id/citations?hl=id\&au thuser=1\&user=wYNVW3UAAAAJ

Heni Susilawati merupakan dosen Sekolah Tinggi Pariwisata AMPTA Yogyakarta yang memiliki fokus kajian dalam bidang manajemen kepariwisataan.

Id Scholar :

https://scholar.google.co.id/citations?hl=id\&au thuser $=1 \&$ user $=$ oRQ29RYAAAAJ

Hary Hermawan, merupakan dosen Sekolah Tinggi Pariwisata AMPTA Yogyakarta yang memiliki fokus kajian dalam bidang manajemen kepariwisataan.

Id Scholar :

https://scholar.google.co.id/citations?user=OP1

9i9oAAAAJ\&hl=id\&authuser $=1$ 